\title{
Analisis Faktor Yang Mempengaruhi Likuiditas Pada Perusahaan Asusransi yang Terdaftar di Bursa Efek Indonesia
}

\author{
Jusmarni, Asepma Hygi Prihastuti \\ Sekolah Tinggi Ilmu Ekonomi Persada Bunda, Riau, Indonesia \\ Email: 1,*jusmarni@ stiepersadabunda.ac.id, ²asepma@ stiepersadabunda.ac.id \\ Email Penulis Korespondensi: jusmarni@ stiepersadabunda.ac.id \\ Submitted: 16/11/2021; Accepted: 25/11/2021; Published: 30/11/2021
}

\begin{abstract}
Abstrak-Penelitian ini bertujuan untuk menguji pengaruh Rasio Utang, Rasio Arus Kas, Rasio Perputaran Modal terhadap likuiditas pada perusahaan Asuransi umum yang terdaftar di BEI 2017-2019. Dimana beberapa tahun ini Industri keuangan khususnya sektor asuransi Indonesia tengah dihadapkan pada sejumlah problematika yang menyebabkan perusahaan asuransi mengalami masalah di sisi likuiditas dan insolvabilitas. Berdasarkan purposive sampling, jumlah sampel yang digunakan dalam penelitian adalah sebanyak 14 perusahaan dari 42 perusahaan observasi. Pengujian hipotesis menggunakan regresi linier berganda. Hasil penelitian menunjukkan bahwa Rasio Utang dan Rasio Perputaran Modal tidak memiliki berpengaruh terhadap likuiditas perusahaan. Sedangkan Rasio Arus Kas memiliki pengaruh terhadap Likuiditas Perusahaan Asuransi yang terdaftar di Bursa Efek Indonesia
\end{abstract}

Kata Kunci: Rasio Utang; Rasio Arus Kas; Rasio Perputaran Modal; Likuiditas

Abstract-This study aims to examine the effect of Debt Ratio, Cash Flow Ratio, Capital Turnover Ratio on liquidity in general insurance companies listed on the Indonesia Stock Exchange 2017-2019. In recent years, the financial industry, especially the Indonesian insurance sector, has been faced with a number of problems that have caused insurance companies to experience problems in terms of liquidity and insolvency. Based on purposive sampling, the number of samples used in the study were 14 companies from 42 observation companies. Hypothesis testing using multiple linear regression. The results showed that the Debt Ratio and Capital Turnover Ratio had no effect on the company's liquidity. While the Cash Flow Ratio has an influence on the Liquidity of Insurance Companies listed on the Indonesia Stock Exchange

Keywords: Debt Ratio; Cash Flow Ratio; Capital Turnover Ratio; Liquidity

\section{PENDAHULUAN}

Perusahaan asuransi merupakan lembaga keuangan non bank yang mempunyai peranan yang tidak jauh berbeda dari bank, yaitu bergerak dalam bidang layanan jasa yang diberikan kepada masyarakat dalam mengatasi risiko yang terjadi di masa yang akan datang. Pertanggungan risiko yang memberikan penggantian karena kerugian, kerusakan, biaya yang timbul, kehilangan keuntungan, atau tanggung jawab hukum kepada pihak ketiga yang mungkin diderita tertanggung atau pemegang polis karena terjadinya suatu peristiwa.

Perkembangan perusahaan asuransi di Indonesia mengalami perkembangan yang cukup pesat setelah pemerintah mengeluarkan deregulasi pada tahun 1980an dan diperkuat dengan keluarnya UU No. 2 Tahun 1992 tentang Usaha Perasuransian. Dengan adanya deregulasi tersebut, pemerintah memberikan kemudahan dalam hal perijinan, sehingga mendorong tumbuhnya perusahaan- perusahaan baru, dan pada gilirannya akan meningkatkan hasil produksi nasional.

Asuransi merupakan salah satu instrumen penting dari lembaga keuangan karena tujuan akhirnya adalah menuju kesejahteraan masyarakat. Umumnya, lembaga asuransi menawarkan jasa-jasa yang berupa proteksi terhadap penciptaanrasa aman dan rasa terlindungi, sehingga orang dalam menjalani kehidupan ekonominya menjadi tentram dan dengan demikian dapat meningkatkan produktivitasnya. Semua perusahaan asuransi rata-rata mengklaim dirinya yang terbaik. Sejumlah keunggulan dikemukakan perusahaan asuransi tersebut untuk menyakinkan banyak orang. Bisa saja apa yang dikemukakannya berbeda dengan pandangan setiap orang.

Kasus gagal bayar industri keuangan kembali muncul. Kasus gagal bayar klaim perusahaan asuransi kepada nasabah dalam sepuluh tahun terakhir membuat cemas masyarakat. Apalagi kasus gagal bayar tersebut terjadi pada perusahaan-perusahaan asuransi besar membuat harapan publik terhadap industri asuransi pupus (CNBC Indonesia, 2020). Seperti yang terjadi baru-baru ini pada PT Asuransi Jiwasraya yang tengah terbelitmasalah likuiditas. Alhasil, perusahaan asuransi milik negara ini menunda pembayaran polis yang jatuh tempo produk bancassurance asuransi jiwa yang berbalut investasi atau saving plan yang dijual bersama sejumlah bank sebagai agen penjual. Berikut nama perusahaan yang kasusnya masih bergulir akibat gagal bayar: PT Asuransi Jiwa Kresna (Kresna Life), PT Asuransi Jiwasraya (Persero), PT Asuransi Jiwa Bakrie Life, PT Asuransi Bumi Asih Jaya dan PT Asuransi Jiwa Bumiputera 1912 (https://www.cnbcindonesia.com. 2020)

Sebenarnya, kriteria asuransi berkinerja baik bisa diketahui dari sejumlah tolok ukur yang biasa digunakan untuk membuat peringkat kinerja perusahaan asuransi. Laporan keuangan merupakan salah satu sumber informasi yang penting selain kondisi perekonomian, disitulah tersusun daftar perusahaan-perusahaanasuransi berkinerja baik. Salah satu mengukur kinerja Asuransi adalah bagaimanarasio likuiditas perusahaan Asuransi, yaitu seberapa mampu perusahaan asuransi untuk mengelola keuangan dengan baik dan seberapa mampu dalam memenuhi kewajiban semisal utang tergantung dari rasio likuiditas.

Risiko likuiditas adalah risiko yang muncul akibat kesulitan menyediakan uang tunai dalam jangka waktu tertentu. Misalnya: jika suatu pihak tidak dapat membayar kewajibannya yang jatuh tempo secara tunai. likuiditas 
adalah kemampuan sebuah perusahaan dalam melunasi utang serta kewajiban jangka pendek yang dimiliki. Alat pemenuhan kewajiban keuangan jangka pendek ini berasal dari unsur-unsur aktiva yang bersifat likuid. Rasio Likuiditas merupakan rasio yang menggambarkan kemampuan perusahaan dalam memenuhi kewajiban (utang) jangka pendek

Pengamatan tentang faktor yang mempengaruhi Likuiditas talah banyak diamati, diantaranya penelitian yang dilakukan Lisa Puspitasari dkk (2013) meneliti Analisa Faktor yang Mempengaruhi Likuiditas Pada Industri Ritel yang Terdaftar Pada Bursa Efek Indonesia Tahun 2007-2012. Hasil pengujian Modal kerja mempengaruhi likuiditas perusahaan, sedangkan Ukuran Perusahaan dan Kesempatan Bertumbuh tidak mempengaruhi likuiditas. Dhian dkk (2015) menganalisis factor-faktor yang mempengaruhi likuiditas pada Industry Pertanian, Kehutanan dan Perikanan, dan Industri Otomotif. Hasil penelitian cuma Perputaran piutang yang berpengaruh terhadap likuiditas Industry Pertanian, Kehutanan dan Perikanan, dan Industri Otomotif, sedangkan Pertumbuhan penjualan dan Modal kerja tidak memiliki pengaruh terhadap likuiditas pada Industry Pertanian, Kehutanan dan Perikanan, dan Industri Otomotif. Misnawati (2019) Analisa Faktor yang Mempengaruhi Likuiditas Pada Industri Ritel yang Terdaftar Pada Bursa Efek Indonesia Tahun 2010-2017 Hasil penelitian ini menunjukkan bahwa secara simultan variabel ukuran perusahaan, kesempatan bertumbuh, perputaran modal kerja, dan rasio hutang berpengaruh positif dan signifikan terhadap likuiditas. Sedangkan secara parsial variabel ukuran perusahaan, perputaran modal kerja dan rasio hutang berpengaruh negatif dan signifikan terhadap likuiditas, sedangkan kesempatan bertumbuh berpengaruhnegatif dan tidak signifikan terhadap likuiditas.

Selain dari beberapa factor yang diduga mempengaruhi likuiditas telah dianalisis oleh peneliti diatas, untuk mengetahui kemampuan finansial sebuah perusahaan berdasarkan seberapa besar perusahaan tersebut bertumpu pada utang untuk membiayai operasional dan aset perusahaan biasanya digunakan rasio utang. Dengan menghitung rasio utang, pengusaha dapat mengetahui berapa banyak utang perusahaan dibandingkan dengan aset yang dimiliki. Sementara bagi kreditur, menghitung rasio utang bisa berguna untuk mengetahui besar atau kecilnya risiko saat memberikan pinjaman kepada perusahaan tertentu karena prosentase rasio menunjukkan seberapa besar aset perusahaan yang disediakan melalui utang. Selain utang Arus kas perusahaan juga menuntukan kondisi finansial perusahaan.

Arus kas adalah kenaikan atau penurunan jumlah uang yang dimilikiperusahaan. Dalam perusahaan, aktivitas normal adalah aktivitas utama yang merupakan kegiatan yang terus menerus. Ketidak cukupan menghasilkan arus kasdari aktivitas utama untuk membayar kewajiban dari aktivitas normal bisa mengakibatkan kebangkrutan perusahaan. Selain Arus Kas, modal juga memiliki peran dalam likuiditas.

Modal merupakan faktor yang sangat penting bagi perusahaan untuk menjalankan aktivitas operasional sehari-hari Modal kerja selalu dalam keadaan berputar atau beroperasi dalam perusahaan selama perusahaan yang bersangkutan dalam keadaan usaha. Periode perputaran modal kerja (working capital turnorver)dimulai saat kas diinvestasikan dalam komponen modal kerja sampai saat dimana kas kembali lagi menjadi kas. Makin pendek periode tersebut berarti makin cepat perputarannya atau makin tinggi tingkat perputarannya (turnorver rate-nya). Menurut Kasmir dalam Caesarani (2014) perputaran modal kerja adalah salah satu rasio untuk mengukur atau menilai keefektifan modal kerja perusahaan selama periode tertentu.

Modal kerja memiliki sifat yang fleksibel, besar kecilnya modal kerja dapat ditambah atau dikurangi sesuai kebutuhan perusahaan. Perputaran modal kerja yang tinggi diakibatkan rendahnya modal kerja yang ditanam dalam persediaan dan piutang, atau dapat juga menggambarkan tidak tersedianya modal kerja yang cukup dan adanya perputaran persediaan dan perputaran piutang yang tinggi. Jika perputaran persediaan dan perputaran piutang tinggi, berarti perusahaan tidak membutuhkan saldo persediaan dan saldo piutang yang besar, dengan demikian maka jumlah modal kerja pun tidak terlalu besar. Dalam penentuan kebijakan modal kerja yang efisien, perusahaan dihadapkan pada masalah adanya pertukaran (trade off) antara faktor likuiditas dan profitabilitas (Supriyadi dan Fazriani, 2011). Jika perusahaan memutuskan menetapkan modal kerja dalam jumlah yang besar, kemungkinan tingkat likuiditas akan terjaga

\section{METODE PENELITIAN}

\subsection{Laporan Keuangan}

Laporan keuangan adalah laporan yang menunjukkan kondisi keuangan perusahaan pada saat ini atau dalam suatu periode tertentu, maksudnya keadaan keuangan perusahaan pada tanggal tertentu untuk neraca dan periode tertentu untuk laporan laba rugi" (Kasmir, 2016:7).

\subsection{Rasio Keuangan}

Menghitung rasio keuangan merupakan kegiatan membandingkan angka- angka yang ada dalam laporan keuangan dengan cara membagi satu angka denganangka lainnya. Angka yang diperbandingkan dapat berupa angka-angka dalam satu periode maupun beberapa periode" (Kasmir, 2016:104

\subsection{Likuiditas}


Likuiditas adalah kemampuan sebuah perusahaan dalam melunasi utang serta kewajiban jangka pendek yang dimiliki. Utang jangka pendek perusahaan tersebut meliputi utang usaha, pajak, dividen, dan lain sebagainya. Likuiditas menunjukan kemampuan suatu perusahaan untuk memenuhi kewajibankeuangannya yang harus segera dipenuhi, atau kemampuan perusahaan untuk memenuhi kewajiban keuangan pada saat ditagih (Munawir 2010: 31). Likuiditas dapat juga dikatakan yaitu kemampuan perusahaan untuk memperoleh aset lancar yang bagus dalam memenuhi kewajiban keuangannya dengan tepat waktu utang dengan segera menggunakan harta lancar yang dimiliki

\subsection{Rasio Likuiditas}

Rasio Likuiditas merupakan rasio yang menggambarkan kemampuan perusahaan dalam memenuhi kewajiban (utang) jangka pendek. Artinya apabila perusahaan ditagih, perusahaan akan mampu memenuhi utang tersebut terutama utang yang sudah jatuh tempo" (Kasmir, 2016:110). Likuiditas merupakan rasio yang digunakan untuk mengukur tingkat pengembalian kewajiban lancar pada perusahaan. Likuiditas umumnya diukur dengan perbandingan antara aktiva lancar dengan hutang lancar yang disebut rasio lancar atau current ratio. Namun tidak semua perusahaan yang menggunakan rasio tersebut. sebab rasio likuiditas memiliki beberapa alat ukur, seperti Quick ratio, Cash ratio ataupun ratio likuiditas lainnya. Menurut Syafrida Hani (2015, hal,122) menyatakan bahwa likuiditas dapat diukur menggunakan rasio-rasio, yaitu : (1) Current ratio. merupakan alat ukur bagi kemampuan likuidtas yaitu kemampuan untuk membayar hutang yang segera harus dipenuhi dengan aktiva lancar. (2) Quick ratio, merupakan alat ukur untuk menilai kemampuan perusahaan dalam membayar gutang yang segera harus di penuhi dengan aktiva lancaryang likuid. dan (3) Cash ratio, merupakan alat ukur untuk menilai kemampuan perusahaan dalam membayar hutang dengan sejumlah kas yang dimiliki perusahaan. Dalam penelitian ini Peneliti hanya menggunakan Current Ratio sebagai alat ukur dalam menilai tingkat likuiditas perusahaan.

\subsection{Faktor yang memepengaruhi Likuiditas}

Dalam menentukan tingkat likuiditas perusahaan, maka pihak manajemen perlu mempertimbangkan beberapa faktor yang dapat mempengaruhi. Faktor- faktor tersebut antara lain: Menurut syafrida Hani (2015, hal,121) menyatakan bahwa :"faktor-faktor yang dapat mempengaruhi likuiditas adalah unsur pembentuk likuiditas itu sendiri yakni bagian dari aktiva lancar dan kewajiban lancar, termasuk perputaran kas, dan arus kas operasi, ukuran perusahaan, kesempatan bertumbuh (growth opportunities), keragaman arus kas operasi, rasio utang atau struktur utang."

\subsubsection{Rasio Utang}

Rasio utang atau dalam bahasa Inggris disebut dengan Debt Ratio adalahRasio yang digunakan untuk mengukur seberapa besar perusahaan mengandalkanhutang untuk membiayai asetnya. Rasio Hutang ini dapat menunjukan proporsi hutang perusahaan terhadap total aset yang dimilikinya. Para Investor dapat menggunakan Rasio Hutang atau Debt Ratio ini untuk mengetahui berapa banyakhutang yang dimiliki oleh perusahaan dibandingkan dengan asetnya. Kreditur juga dapat mengukur seberapa tinggi risiko yang diberikan kepada suatu perusahaan. Semakin tinggi rasionya, semakin besar pula risiko yang terkait dengan operasional perusahaan. Sedangkan rasio utang yang rendah mengindikasikan pembiayaan konservatif dengan kesempatan untuk meminjam di masa depan tanpa risiko yang signifikan. Rendahnya Rasio Hutang juga memiliki arti hanya sebagian kecil aset perusahaan yang dibiayai dari Hutang.

\subsubsection{Keragaman Arus Kas}

Laporan arus kas atau yang biasa disebut dengan cash flow ini sendiri dapat diartikan sebagai catatan keuangan yang berisi informasi tentang pemasukandan pengeluaran selama satu periode. Didaam laporan arus kas berisi aktivitas perusahaan yaitu aktivitas operasi, aktivitas investasi dan aktivitas pendanaan. Laporan ini akan sangat berguna ketika akan mengevaluasi struktur keuangan (likuiditas dan solvabilitas), serta aktiva bersih perusahaan. Tak hanya itulaporan arus kas bisa memanfaatkannya sebagai strategi adaptif menghadapi perubahan keadaan dan peluang. Rasio arus kas menghitung kemampuan kas dalam membayar kewajiban lancar. Rasio ini diperoleh dengan membagi kas dengan kewajiban lancar.Rasio yang menunjukkan bahwa rasio arus kas operasi berada dibawah satu yang berarti terdapat kemungkinan perusahaan tidak mampu membayar kewajiban lancar,tanpa menggunakan arus kas dari aktivitas lain. Dalam perusahaan, aktivitas normal adalah aktivitas utama yang merupakan kegiatan yang terus menerus. Ketidakcukupan menghasilkan arus kas dari aktivitas utama untuk membayar kewajiban dari aktivitas normal bisa mengakibatkan kebangkrutan perusahaan. Karena masalah terbesar dalam kebangkrutan biasanya akibat ketidak mampuan dalam membayar kewajiban jangka pendek.

\subsubsection{Perputaran Modal}

Modal merupakan faktor yang sangat penting bagi perusahaan untuk menjalankan aktivitas operasional sehari-hari. Modal kerja selalu dalam keadaan berputar atau beroperasi dalam perusahaan selama perusahaan yang bersangkutan dalam keadaan usaha. Periode perputaran modal kerja (working capital turnorver)dimulai saat kas diinvestasikan dalam komponen modal kerja sampai saat dimanakas kembali lagi menjadi kas. Makin pendek periode tersebut berarti makin cepat perputarannya atau makin tinggi tingkat perputarannya (turnorver rate- nya). Menurut Kasmir 
dalam Caesarani (2014) perputaran modal kerja adalah salah satu rasio untuk mengukur atau menilaikeefektifan modal kerja perusahaan selama periode tertentu. Perputaran modal kerja yang tinggi diakibatkan rendahnya modal kerja yang ditanam dalam persediaan dan piutang, atau dapat juga menggambarkan tidak tersedianya modal kerja yang cukup dan adanya perputaran persediaan dan perputaran piutang yang tinggi. Jika perputaran persediaan dan perputaran piutangtinggi, berarti perusahaan tidak membutuhkan saldo persediaan dan saldo piutang yang besar, dengan demikian maka jumlah modal kerja pun tidak terlalu besar.

\subsection{Penelitian Terdahulu}

Tabel 1. Penelitian Terdahulu

\begin{tabular}{|c|c|c|c|}
\hline Nama & Judul & Sumber & Hasil Penelitian \\
\hline \multirow{5}{*}{$\begin{array}{l}\text { Lisa Puspitasari } \\
\text { Sugiono dan Y. } \\
\text { Jogi Christiawan } \\
\text { (2013) }\end{array}$} & Analisa & B USINESS & \multirow{5}{*}{$\begin{array}{l}\text { Hasil pengujian Ukuran Perusahaan } \\
\text { dan Kesempatan Bertumbuh tidak } \\
\text { mempengaruhi likuiditas, sedangkan } \\
\text { Modal kerja mempengaruhi likuiditas } \\
\text { perusahaan }\end{array}$} \\
\hline & Mempengaruhi Likuiditas & \multirow{4}{*}{$\begin{array}{l}\text { ACCOUNTING } \\
\text { REVIEW, VOL. 1, No. 2, } \\
2013\end{array}$} & \\
\hline & Pada Industri Ritel yang & & \\
\hline & Terdaftar Pada Bursa Efek & & \\
\hline & $\begin{array}{l}\text { Indonesia Tahun 2007- } \\
2012\end{array}$ & & \\
\hline
\end{tabular}

Dhini, A., Analisis Perbandingan Jurnal Ilmu Manajemen

Minar Savitri \& Faktor-Faktor yang dan Akuntansi Terapan

Harum Indinah Mempengaruhi (J'MAT) Volume 6

Dianingsih Likuiditas pada Industri Nomor 2

(2015) Pertanian, Kehutanan

dan Perikanan, dan

Industri Ototmotif (Studi

Empiris Pada Industri

Pertanian, Kehutanan

dan Perikanan, dan

Industri Otomotif yang

Terdaftar di BEI Tahun

2008-2012).

$\begin{array}{ll}\text { Misnawati } & \text { Analisa Faktor yang } \\ \text { Mempengaruhi } \\ & \text { Likuiditas Pada Industri } \\ & \text { Ritel yang Terdaftar } \\ & \text { Pada Bursa Efek } \\ & \text { Indonesia Tahun 2010- } \\ & \text { 2017: }\end{array}$

Jurnal AKRAB JUARA

Volume 4 Nomor 3 Edisi

Agustus 2019 (130-142)

\begin{abstract}
Hasil penelitian cuma Perputaran piutang yang berpengaruh terhadap likuiditas Industry Pertanian, Kehutanan dan Perikanan, dan Industri Otomotif, sedangkan Pertumbuhan penjualan dan Modal kerja tidak memiliki pengaruh terhadap likuiditas pada Industry Pertanian, Kehutanan dan Perikanan, dan Industri Otomotif
\end{abstract}

Hasil penelitian ini menunjukkan bahwa secara simultan variabel ukuran perusahaan, kesempatan bertumbuh, perputaran modal kerja, dan rasio hutang berpengaruh positif dan signifikan terhadap likuiditas. Sedangkan secara parsial variabel ukuran perusahaan, perputaran modal kerja dan rasio hutang berpengaruh negatif dan signifikan terhadap likuiditas, sedangkan kesempatan bertumbuh berpengaruh negatif dan tidak signifikan terhadap likuiditas.

\subsection{Teknik Pengumpulan Data dan Analisa}

Teknik pengumpulan data dilakukan dengan teknik content analysis (analisis isi) berupa dokumentasi dari perusahaan Asuransi umum yang listing di Bursa Efek Indonesia (BEI) tahun 2017- 2019. Terdapat 47 perusahaan Asuransi umum yang listing di Bursa Efek Indonesia (BEI) sampai tahun 2019, namun yang mempublikasikan laporan keuangan secara konsisten selama tiga tahun hanya 14 perusahaan.

Statistik deskriptif digunakan untuk menganalisa data dengan menggambarkan atau mendeskripsikan data yang sudah terkumpul sebagaimana adanya tanpa maksud membuat kesimpulan yang berlaku umum atau generalisasi (Sugiyono, 2017). Uji ini bertujuan agar diketahui ringkasan umum tentang penelitian ini.

Pengujian hipotesis dilakukan dengan menggunakan data sekunder berupa laporan keuangan yang diperoleh dari Bursa Efek Indonesia. Laporan keuangan yang dibutuhkan adalah laporan keuangan tahun 2017-2019. Hipotesis akan diuji dengan menggunakan model regresi linear berganda. Model analisis yang digunakan dalam penelitian ini adalah :

Likuditas $=\mathrm{a}+\mathrm{b} 1$ rasio utang $+\mathrm{b} 2 \mathrm{X}_{\text {rasio arus }}$ kas $+\mathrm{b} 3 \mathrm{X}_{\text {rasio perputaran modal }}+\mathrm{e}$

Sebelum melakukan uji hipotesis, akan dilakukan uji asumsi klasik meliputi uji normalitas, uji multikolinearitas, uji heteroskedastisitas, dan uji autokolerasi. Uji asumsi klasik dilakukan untuk memastikan bahwa data tidak mengalami gangguan sehingga layak untuk diuji. Uji hipotesis akan dilakukan dengan menggunakan uji F dan uji t. Uji F dilakukan 
untuk melihat pengaruh independent variable secara simultan terhadap dependent varibel. Sedangkan uji t dilakukan untuk melihat pengaruh independent variable secara parsial terhadap dependent variable

\section{HASIL DAN PEMBAHASAN}

\section{Uji Normalitas Data}

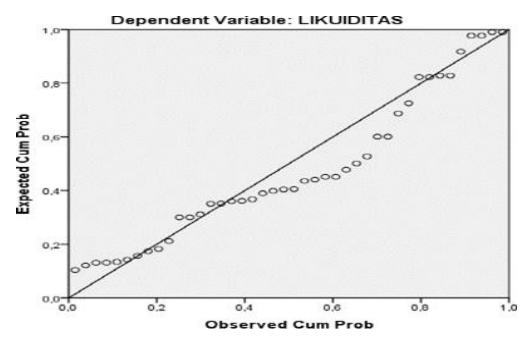

Gambar 1. Probability Plot

Normalitas, Menurut Imam Ghozali $(2011,261)$ Model regresi dikatakan berdistribusi normal jika data ploting (titik titik) yang menggambar data sesungguhnya mengikuti garis diagonal. Pada gambar 5.1 Model berdistribusi normal

\section{Uji Multikolinearitas data}

Tabel 2. Uji Multikoloniearitas

\begin{tabular}{|c|c|c|c|c|c|c|c|c|}
\hline \multirow[b]{2}{*}{ Model } & & \multicolumn{2}{|c|}{$\begin{array}{l}\text { Unstandardized } \\
\text { Coefficients }\end{array}$} & \multicolumn{2}{|l|}{$\begin{array}{l}\text { Standardized } \\
\text { Coefficients }\end{array}$} & \multirow[b]{2}{*}{ Sig. } & \multicolumn{2}{|c|}{ Collinearity Statistics } \\
\hline & & $\mathrm{B}$ & Std. Error & Beta & $\mathrm{t}$ & & Tolerance & VIF \\
\hline 1 & (Constant) & 517,530 & 161,878 & & 3,197 &, 003 & & \\
\hline & RU (X1) &,- 774 & 2,247 &,- 045 &,- 344 &, 732 & ,947 & 1,056 \\
\hline & RAK (X2) & 8,250 & 1,721 & ,613 & 4,792 &, 000 & ,976 & 1,024 \\
\hline & RPM (X3) & $-12,211$ & 23,141 &,- 068 &,- 528 & 601 & ,969 & 1,032 \\
\hline a. Depe & ndent Variab & LIKUIDI & $\mathrm{AS}(\mathrm{Y})$ & & & & & \\
\hline
\end{tabular}

Multikoloniaritas, Menurut Imam Ghozali (2011,107-108) Tidak terjadi gejala multikoloniaritas jika nilai Tolerance $>0,100$ dan nilai VIF < 10,00. Dari Tabel.2 Untuk R.Utang Nilai Tolerance 0,947 > 0,100 dan nilai VIF $1,056<10,00$. Untuk R.Arus Kas nilai Tolernce $0,976>0,100$ dan nilai VIF $1,024<10,000$, dan Untuk R.Perputaran Modal Nilai Tolerance 0,969 > 0,100 dan nilai VIF 1,032 < 10,00. Jadi kesimpulannya Tidak ada gejala Multikolonieritas

\section{Uji Heteroskedastisitas}

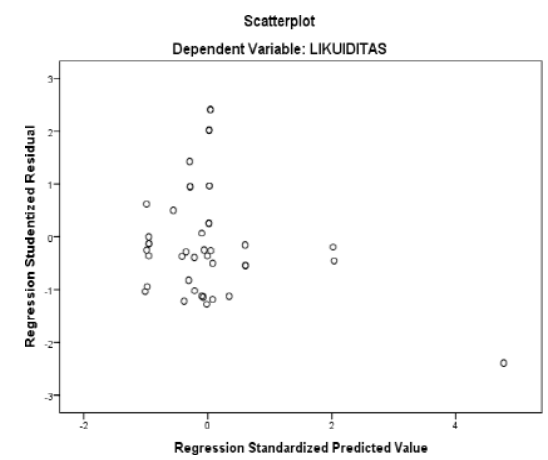

Gambar 2. Scatterplot

Heterokedasitias, Menurut Imam Ghozali (2011:139) Tidak terjadiHeterokedasitias jika ada pola yang jelas (mengelembung, melebar kemudian menyempit) pada Gambar di atas menunjukkan bahwa titik-titik menyebar secara acak di atas dan di bawah angka 0 pada sumbu Y, dan tidak membentuk suatu pola tertentu, maka dapat disimpulkan bahwa tidak terjadi heteroskedastisitas. 


\section{Uji Autokolerasi}

Uji autokorelasi bertujuan untuk menguji apakah dalam suatu model linier terdapat kesalahan pengganggu pada periode $\mathrm{t}$ dengan kesalahan pada periode sebelumnya (t-1). Uji Autokorelasi dapat dilihat dari besarnya nilai Durbin Watson

Tabel 3. Hasil uji autokolerasi

\begin{tabular}{|c|c|c|c|c|c|}
\hline Model & $\mathrm{R}$ & R Square & $\begin{array}{l}\text { Adjusted R } \\
\text { Square }\end{array}$ & $\begin{array}{l}\text { Std. Error of the } \\
\text { Estimate }\end{array}$ & Durbin-Watson \\
\hline 1 &, $627^{\mathrm{a}}$ &, 393 & & 312,509 & 1,215 \\
\hline
\end{tabular}

a. Predictors: (Constant), RPM (X3), RAK (X2), RU (X1)

b. Dependent Variable: LIKUIDITAS (Y)

Sumber: Olahan SPSS 2021

Dari tabel di atas diketahui nilai adjusted R Square sebesar 0.345. Hal ini berarti ke 3 variabel bebas dalam penelitian ini mempengaruhi $34,5 \%$, erhadap likuiditas sedangkan sebesar $65,5 \%$ dipengaruhi oleh faktor-faktor lain di luar penelitian ini.

\section{Uji Hipotesa}

1. Uji F

Tabel 4. Hasil uji f

\begin{tabular}{lrrrrr}
\hline Model & Sum of Squares & df & Mean Square & F & \multicolumn{1}{c}{ Sig. } \\
\hline Regression & 2399062,119 & 3 & 799687,373 & 8,188 &, $000^{\mathrm{b}}$ \\
Residual & 3711162,286 & 38 & 97662,165 & & \\
Total & 6110224,405 & 41 & & & \\
$\begin{array}{l}\text { a. Dependent Variable: LIKUIDITAS (Y) } \\
\text { b. Predictors: (Constant), RPM (X3), RAK (X2), RU (X1) }\end{array}$ & & & \\
\hline
\end{tabular}

Berdasarkan Tabel diatas uji anova mengasilkan angka $F$ sebesar 9.841 dengan tarif signifikansi $(0,000)$ yang dapay diartikan bahwa $\mathrm{F}_{\text {hitung }}>$ dari $\mathrm{F}_{\text {tabel }}$ atau 8,188 > 2,85 dan angka probabilitas $0.000<$ dari 0.005 , maka secara Bersama-sama atau secara simultan dapat dikatakan bahwa Rasio Utang, Rasio Arus Kas dan Rasio Perputaran Modal berpengaruh secara Bersama-sama terhadap Likuiditas perusahaan pada PT Asuransi yang terdaftar di Bursa Efek Indonesia

\section{Uji t}

Tabel 5. Hasil Uji t

\begin{tabular}{llrrrrr}
\hline & \multicolumn{5}{c}{$\begin{array}{c}\text { Unstandardized } \\
\text { Coefficients }\end{array}$} & \multicolumn{2}{c}{$\begin{array}{c}\text { Standardized } \\
\text { Coefficients }\end{array}$} \\
Model & & \multicolumn{1}{c}{ B } & Std. Error & Beta & \multicolumn{1}{c}{ t } & \multicolumn{1}{c}{ Sig. } \\
\hline 1 & (Constant) & 517,530 & 161,878 & & 3,197 &, 003 \\
& RU (X1) &,- 774 & 2,247 &,- 045 &,- 344 &, 732 \\
& RAK (X2) & 8,250 & 1,721 &, 613 & 4,792 &, 000 \\
& RPM (X3) & $-12,211$ & 23,141 &,- 068 &,- 528 &, 601
\end{tabular}

a. Dependent Variable: LIKUIDITAS (Y)

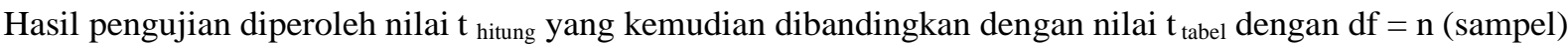
- $\mathrm{k}$ (jumlah variabel independen) dan alpha 0,05, maka diperoleh nilai t table 2,024. Untuk pengujian variable Rasio Utang (X1) $t_{\text {hitung }}<t_{\text {tabel }}$ dengan nilai $-0,774<2,024$, yang artinya Rasio Utang tidak memiliki pengaruh terhadap Likuiditas peusahaan Asuransi di Bursa EFek Indonesia. Untuk pengujian variable Rasio Arus Kas (X2) $t$ hitung $>t$ tabel dengan nilai 8,250 > 2,024, yang artinya Rasio Arus Kas memiliki pengaruh terhadap Likuiditas peusahaan Asuransi di Bursa EFek Indonesia, sementara Rasio Perputaran Modal (X3) dengan nilai -12,211 < 2,024, yang artinya Rasio Perputaran Modal tidak memiliki pengaruh terhadap Likuiditas peusahaan Asuransi di Bursa EFek Indonesia.

\section{Uji Koefesien Diterminan}

Tabel 6. Uji koefesien diterminan

\begin{tabular}{lrrrrrr}
\hline Model & \multicolumn{2}{c}{$\begin{array}{c}\text { Adjusted R } \\
\text { Square }\end{array}$} & $\begin{array}{c}\text { Std. Error of the } \\
\text { Estimate }\end{array}$ & Durbin-Watson \\
\hline 1 & R & R Square & \multicolumn{2}{c}{ Squar }
\end{tabular}

a. Predictors: (Constant), RPM (X3), RAK (X2), RU (X1)

b. Dependent Variable: LIKUIDITAS (Y) 
Dari tabel di atas diketahui nilai adjusted R Square sebesar 0.345. Hal ini berarti ke 3 variabel bebas dalam penelitian ini mempengaruhi 34,5\%, erhadap likuiditas sedangkan sebesar 65,5\% dipengaruhi oleh faktor-faktor lain di luar penelitian ini

\section{KESIMPULAN}

Hasil dari penelitian pengaruh Rasio Utang Rasio Arus Kas dan Rasio Perputaran Modal terhadap likuiditas pada Asuransi perusahaan yang terdaftar di Bursa Efek Indonesia tahun 2017- 2019 dapat disimpulkan: Rasio Utang dan Rasio Perputaran Modal tidak memiliki pengaruh terhadap likuiditas perusahaan Asuransi yang terdaftar dibursa Efek Indonesia tahun 2017-2019 sementara Rasio Arus Kas dan Rasio Perputaran Modal terhadap memiliki pengaruh terhadap likuiditas perusahaan Asuransi yang terdaftar dibursa Efek Indonesia tahun 2017-2019

\section{REFERENCES}

Dhini, A., Minar Savitri \& Harum Indinah Dianingsih (2015). Analisis Perbandingan Faktor-Faktor yang Mempengaruhi Likuiditas pada Industri Pertanian, Kehutanan dan Perikanan, dan Industri Ototmotif (Studi Empiris Pada Industri Pertanian, Kehutanan dan Perikanan, dan Industri Otomotif yang Terdaftar di BEI Tahun 2008-2012). Jurnal Ilmu Manajemen dan Akuntansi Terapan (J'MAT) Volume 6 Nomor 2

Hani, Syafrida. 2015. Teknik Analisa Laporan Keuangan. Medan: UMSU PRESS Harahap,

Lisa Puspitasari Sugiono dan Y. Jogi Christiawan (2013). Analisa Faktor yang Mempengaruhi Likuiditas Pada Industri Ritel yang Terdaftar Pada Bursa Efek Indonesia Tahun 2007-201. Jurnal BUSINESS ACCOUNTING REVIEW, VOL. 1, No. 2, 2013

Kasmir. 2012. Analisis Laporan Keuangan. PT. RAJA GRAFINDO PERSADA: Jakarta

Kim, C. S., Mauer, D. C., \& Sherman, A. E. (1998). The Derterminants of Coorporate Liquidity: Theory and Evidence. Journal of Financial andQualitative Analysis, 335.

Kitab Undang-undang Hukum Dagang, Pasal 246 KUHD.Tentang Asuransi Marlina, Reni, dan Dwi Puryati, 2013. The Influence of Risk Based Capital to

Profitability in Jasindo Insurance Company.South East Asia Journal of Contemporary Business, Economics and Law, vol. 2 no. 1, p. 8-16.

Misnawati (2019) Analisa Faktor yang Mempengaruhi Likuiditas Pada Industri Ritel yang Terdaftar Pada Bursa Efek Indonesia Tahun 2010-2017: Jurnal AKRAB JUARA Volume 4 Nomor 3 Edisi Agustus 2019 (130-142)

Munawir. (2010). Analisa Laporan Keuangan.Yogyakarta: Liberty. Riyanto, B. (2012). Dasar-dasar Pembelanjaan Perusahaan. Yogyakarta: BPFE.

Rejda, G.E., and McNamara, M. (2014) Principles of risk management and insurance. 12th ed. New York: Pearson Education, pp 104-160

Riyanto, B. (2012). Dasar-dasar Pembelanjaan Perusahaan. Yogyakarta: BPFE.

Santoso, Y. A. (2011). Analisis Faktor yang Mempengaruhi Likuiditas Pada perusahaan Manufaktur yang Listed di Bursa Efek Indonesia (BEI) Periode 2007-2009. 